УДК 378.147

\title{
РОЛЬ РОЗРАХУНКОВИХ ЗАДАЧ З МОДУЛІВ “КОЛОЇДНА ХІМІЯ” ТА “ФАРМАЦЕВТИЧНА ХІМІЯ” У ПІДГОТОВЦІ СПЕЦІАЛСТІВ ФАРМАЦІї
}

\author{
Л. М. Іванець, О. Б. Поляк
}

ДВНЗ “Тернопільський держсавниймедичний університет імені І. Я. Горбачевського МОЗ України”

\section{ROLE OF CALCULATION TASKS ON THE MODULES “COLLOIDAL CHEMISTRY” AND "PHARMACEUTICAL CHEMISTRY” IN TRAINING OF PHARMACY SPECIALISTS}

\author{
L. M. Ivanets, O. B. Polyak \\ SHEI "Ternopil State Medical University by I.Ya. Horbachevsky of MPH of Ukraine"
}

\begin{abstract}
Узагальнено досвід викладання колоїдної хімії та фармацевтичної хімії студентам фармацевтичного факультету Тернопільського державного медичного університету імені І. Я. Горбачевського. Звертається увага на професійну орієнтацію при розв'язуванні задач.
\end{abstract}

Experience of teaching of Colloidal Chemistry and Pharmaceutical Chemistry for the students of Pharmaceutical Faculty of Ternopil State Medical University by I. Ya. Horbachevsky is generalized. Attention is focused on a professional orientation at solving the tasks.

Вступ. Будучи прикладною наукою, фармацевтична хімія базується на теорії і законах хімічних наук. Оскільки дія лікарських речовин на організм залежить від їх фізико-хімічних властивостей, то фармацевтична хімія використовує закони фізичної хімії. Практичне засвоєння фізичної та колоїдної хімії вимагає від студентів неодмінного вміння розв'язувати задачі. Для викладачів розв'язування задач - це прекрасний спосіб здійснення міжпредметних зв'язків.

Основна частина. Під час вивчення модуля "Колоїдна хімія" (III курс) у нашому навчальному закладі практикується розв' язування задач зі збірників задач та посібників для студентів фармацевтичних факультетів. Задачі в них складені на основі оригінальних літературних праць іпідібрані таким чином, що відображають практичне застосування фізикохімічних методів у фармації.

На занятті з теми "Поверхневий натяг. Мономолекулярна адсорбція рідиною" студенти вчаться розраховувати вагу краплі, що рівна силі поверхневого натягу, вміст у ній діючої речовини. Це напряму пов'язано з дозуванням рідких крапельних форм. Вплив концентрації і природи розчиненої речовини на величину поверхневого натягу розчинів ілюструють задачі на рівняння Шишковського. При цьому звер() Л. М. Іванець, О. Б. Поляк тається увага студентів на те, що в лікарських формах значення поверхневого натягу служить показником стабільності та біологічної доступності речовин. Знання, отримані на даному занятті з колоїдної хімії, студенти використовують при встановленні доброякісності більшості субстанцій лікарських речовин на заняттях із фармацевтичної хімії.

Ситуаційні задачі, які виносяться на тему “Адсорбційна здатність твердих адсорбентів”, спрямовані на розрахунок питомої поверхні адсорбентів, в тому числі медичного призначення. Крім того, значний відсоток займають задачі, в яких необхідно знайти, скільки максимально може поглинатися отруйної речовини одиницею маси або площі адсорбенту. На занятті з фармацевтичної хімії на тему “Аналіз якості неорганічних лікарських препаратів Арсену, Карбону, Алюмінію, Барію, Аргентуму" студенти визначають адсорбційну здатність субстанції вугілля активованого, що є практичним застосуванням знань, отриманих при вивченні колоїдної хімії.

При розв' язуванні задач на молекулярно-кінетичні властивості дисперсних систем студенти насамперед повинні оволодіти формулами для обчислення швидкості дифузії та швидкості седиментації. Дифузійні параметри залежать від величини концентрації лікарської речовини. Це необхідно враховувати 
при розрахунках кількості лікарської речовини, що переноситься за одиницю часу в різні тканини організму. Оскільки більшість лікарських засобів належать до одного із класів дисперсних систем - порошків, золів, суспензій, емульсій, аерозолів, паст, то першорядним для фармацевтичної практики є питання їх стійкості, зокрема седиментаційної. Зважаючи на це, ряд задач присвячений обчисленню швидкості седиментації і гіпсометричної висоти. Аналізуючи рівняння Стокса і розв' язуючи відповідні задачі, студенти доходять висновку, що підвищити стійкість лікарської форми до седиментації можна, забезпечивши достатньо в'язке дисперсійне середовище i високу дисперсність речовини.

На занятті з теми “Електричні властивості і коагуляція дисперсних систем” основна увага приділяється написанню формул колоїдних міцел і визначенню знаку заряду колоїдних частинок. Від цього студенти відштовхуються, коли виникає необхідність підібрати найбільш ефективний коагулянт, наприклад, 3 метою очищення лікарського засобу або води для його приготування. Важливим $\epsilon$ вміння розраховувати електрофоретичну рухливість, оскільки цей показник має значення при дозуванні кількості лікарської речовини при іï електрофоретичному введенні.

Під час вивчення грубодисперсних систем студенти вчаться визначати тип емульсії за природою дисперсної фази, використовуючи правило Банкрофта, а також розраховують необхідні кількості компонентів для приготування емульсії заданої концентрації. Ці вміння мають велике значення для майбутньої практичної діяльності, зокрема, провізора-технолога.

Під час вивчення теми "Властивості розчинів ВMC” студенти розв' язують задачі на знаходження молекулярної маси за результатами осмометрії та віскозиметрії. У фармації вибір хімічної природи полімеру і його молекулярної маси обумовлюється цільовим призначенням препарату з урахуванням необхідності забезпечення функціональних характеристик та особливостей технологіі.

Усі вищеперераховані знання і навички з колоїдної хімії студенти фармацевтичного факультету використовують під час вивчення профільної дисципліни - фармацевтичної хіміі, зокрема, при встановленні доброякісності субстанцій лікарських речовин та лікарських засобів фізичними та фізико-хімічними методами.

Висновок. Розв'язування задач вимагає від студентів уміння логічно мислити, планувати, робити короткі записи, проводити розрахунки. При цьому не тільки закріплюються знання і навички, отримані раніше, але і формуються нові, відбувається свідоме засвоєння і краще розуміння хімічних теорій, законів і явищ. Задачі повинні стимулювати у студентів інтерес до вивчення хімічних дисциплін, щоб вони розуміли матеріал значно глибше, ніж просто вміти підставити числові значення величин у відповідні формули. Особливо цікавими для студентів є задачі на професійне спрямування, оскільки вони дають змогу зрозуміти, для яких цілей знання з хімічних дисциплін можуть бути використані провізором.

\section{Література}

1. Кабачний В. І. Фізична та колоїдна хімія. Збірник задач : навчальний посібник для студентів вищ. фармац. закладів освіти / В. І. Кабачний. - Харків : Вид-во НФАУ; Вид-во “Золоті сторінки", 2001. - 208 с.

2. Біофізична та колоїдна хімія/ [А. С. Мороз, Л. П. Яворська, Д. Д. Луцевич та ін.]. - Вінниця : Нова Книга, 2007. -600 с.

3. Коробко Д. Б. Методичні рекомендації з фармацевтич- ної хімії для студентів III курсу фармацевтичного факультету (спеціальність “Провізор”) / Д. Б. Коробко, Л. П. Яворська, В. І. Гнідець. - Тернопіль : Укрмедкнига, 2005. - 80 c.

4. Фармацевтичний аналіз / [П. О. Безуглий, В. О. Грудько, С. Г. Леонова та ін.]; за ред. П. О. Безуглого. - Х. : Вид-во НФАУ; Золоті сторінки, 2001.-240 с. 